\title{
Environmental correlates of Freckled Nightjar (Caprimulgus tristigma) activity in a seasonal, subtropical habitat
}

\author{
Robert A. M. Ashdown ${ }^{1}$ and Andrew E. McKechnie ${ }^{1,2}$
}

(1) DST/NRF Centre of Excellence at the Percy FitzPatrick Institute, School of Animal, Plant and Environmental Sciences, University of the Witwatersrand, Private Bag 3, Wits, Johannesburg, 2050, South Africa

(2) Department of Zoology and Entomology, University of Pretoria, Pretoria, 0002, South Africa

Andrew E. McKechnie

Email: aemckechnie@zoology.up.ac.za

\section{Abstract}

We examined environmental correlates of activity in the Freckled Nightjar (Caprimulgus tristigma), a nocturnal aerial insectivore that is resident year-round in the colder and drier parts of southern Africa. Specifically, we tested the prediction that air temperature $\left(T_{\mathrm{a}}\right)$, in addition to light availability, is a significant correlate of Freckled Nightjar activity. We found that aerial insect density varied by over three orders of magnitude (from $<1.0$ to 117.1 insects $1,000 \mathrm{~m}^{-3}$ ) during the course of the study, and was strongly and positively related to $T_{\text {a }}$. Nightjar activity was also significantly temperature-dependent, with a cessation of activity at $T_{\mathrm{a}}<12^{\circ} \mathrm{C}$. Consistent with previous studies, we found that activity levels were strongly related to ambient light, with markedly reduced activity levels on dark nights. The average number of Freckled Nightjars encountered per 14.6-

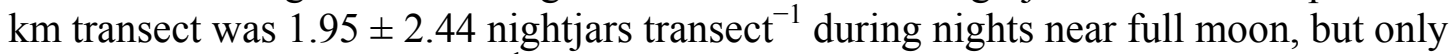
$0.17 \pm 0.61$ nightjars transect ${ }^{-1}$ around new moon. Our study reveals that caprimulgid activity can be significantly influenced by temperature as well as ambient light.

\section{Introduction}

Large temporal and spatial fluctuations in availability make aerial insects a highly variable food resource for consumers (Jetz et al. 2003; Racey and Swift 1985; Rydell et al. 1996; Speakman et al. 2000). The density of aerial insects at a site may vary by 1-3 orders of magnitude within and among seasons, with most variation attributable to rainfall, air temperature ( $T_{\mathrm{a}}$ ), and/or circadian cycles (Jetz et al. 2003; Racey and Swift 1985; Rydell et al. 1996; Speakman et al. 2000). Fluctuations in the availability of aerial insects can potentially lead to mismatches between energy supply and demand for consumers. The potential severity of such mismatches is most pronounced in small 
endotherms that have large surface area-volume ratios, since increased thermogenic energy requirements at low $T_{\text {a }}$ conflict with reduced insect availability (Brigham et al. 2006).

Nearly all avian nocturnal aerial insectivores belong to the suborder Caprimulgi (sensu Sibley and Ahlquist 1990). In contrast to echo-locating bats, caprimulgids are visual predators for whom ambient light represents an additional source of variation in energy intake, since on dark nights light levels may be too low to permit prey detection (Cleere 1999; Holyoak 2001; Jetz et al. 2003). Moonlight is one of the major sources of light available to nocturnal animals, and most studies of caprimulgid foraging activity have assessed the role of lunar light availability (Brigham and Barclay 1992; Brigham et al. 1999; Jetz et al. 2003; Mills 1986; Woods and Brigham 2008). Jetz et al. (2003), for example, found a strong relationship between lunar cycles and the timing of foraging activity by Standard-winged (Macrodipteryx longipennis) and Long-tailed Nightjars (Caprimulgus climacurus) in equatorial west Africa, with a significant increase in crepuscular foraging activity around new moon.

Few studies have investigated the influence of $T_{\mathrm{a}}$ on food availability and foraging activity in caprimulgids. In seasonal subtropical and temperate habitats, temperaturedependent variation in aerial insect density can be considerable. Speakman et al. (2000), for example, reported that aerial insect density decreased rapidly at $T_{\mathrm{a}}<15^{\circ} \mathrm{C}$. We predicted that in a seasonal, subtropical environment, foraging activity in caprimulgids is strongly dependent on $T_{\mathrm{a}}$, as well as ambient light, reflecting the $T_{\mathrm{a}}$-dependence of aerial insect prey. We tested this prediction with the Freckled Nightjar (Caprimulgus tristigma granosus), a year-round resident in colder, drier regions of southern Africa (Spottiswoode and Jackson 2005).

\section{Methods}

\section{Study site}

Our study was conducted in the Kgaswane Mountain Reserve (KMR; 254' $\mathrm{S}, 27^{\circ} 11^{\prime} \mathrm{E}$ ), Northwest Province, South Africa. The reserve is situated near the western end of the Magaliesberg mountain range at ca. 1,400 $\mathrm{m}$ a.s.1., and experiences predominantly summer rainfall. In the town of Rustenburg (ca. $5 \mathrm{~km}$ from study site), the mean daily minimum $T_{\mathrm{a}}$ for the warmest month (January) is $17.3 \pm 0.6^{\circ} \mathrm{C}$, the corresponding value for the coldest month (July) is $2.9 \pm 1.0^{\circ} \mathrm{C}$, and the mean annual precipitation is $612 \pm 181 \mathrm{~mm}$ (weather data for 1970-2005, South African Weather Service). Climatic conditions during our study period were typical for the area, with all monthly mean maximum and minimum $T_{\mathrm{a}}$ values within $2-3^{\circ} \mathrm{C}$ of the respective $1970-2005$ means. Rainfall during January-April 2006 was $449 \mathrm{~mm}$, equivalent to 129\% of the 1970-2005 mean for this period. Nightjars typically roosted on rocky outcrops and boulder-strewn slopes surrounding the savanna in the centre of the reserve. Vegetation in typical roosting habitat consisted of a mix of sparse, short grasses interspersed with dense shrubs, together with small trees among weathered rocks. Fieldwork was conducted during 2006. We visited KMR to collect data eight times, twice in January (summer), twice in March 
(autumn), twice in June (winter) and twice in September (spring). Each pair of visits consisted of one 5-day period at approximately new moon and the other at approximately full moon. We collected data on a total of 40 nights during the year, but did not sample during heavy rain.

\section{Light and weather}

$T_{\mathrm{a}}\left( \pm 0.5^{\circ} \mathrm{C}\right)$ and relative humidity were recorded in the central area of the reserve using a miniature data logger (iButton Thermochron, Dallas Semiconductor, Dallas, USA.) housed in a ventilated white paper cup that was suspended upside-down approximately $3 \mathrm{~m}$ above the ground in the shade. At the end of the study, the iButton was calibrated in a water bath over the $T_{\mathrm{a}}$ range encountered during data collection, using a mercury thermometer (resolution $=0.2^{\circ} \mathrm{C}$ ) with an accuracy traceable to the US National Bureau of Standards. Before assessing insect density on each transect (see below), we scored ambient light on a scale of $0-5$, where $0=$ complete darkness with $100 \%$ cloud cover and/or mist, and $5=$ a completely clear night at full moon. Nights that would otherwise have been completely dark but on which light was visible from the nearby town of Rustenburg were scored as 1 . The times of sunset and moonrise were obtained from a Garmin 76 CS GPS receiver.

\section{Aerial insect density and community composition}

The density of aerial insects was quantified following Jetz et al. (2003). A net with a $1.0 \times 1.0 \mathrm{~m}$ entrance and a length of $2.3 \mathrm{~m}$ was mounted on the roof of a vehicle, with the lower edge of the entrance $1.2 \mathrm{~m}$ behind the top of the windscreen, and $12 \mathrm{~cm}$ above the roof. To sample aerial insect density, the vehicle was driven with lights dimmed at a constant speed of $30 \mathrm{~km} \mathrm{~h}^{-1}$ along a $10.1-\mathrm{km}$ circular transect. Two insect density transects were driven each night, with the direction driven around the route alternated. The first transect commenced 30 min after sunset, and the second started 2-3 h after sunset. At the end of each transect, all insects caught in the net were placed in ethanol for preservation. All insects $<3 \mathrm{~mm}$ in length were discarded since this represents the approximate minimum size for nightjar prey (Jackson 2000; Jetz et al. 2003), and the remainder were identified to order.

\section{Nightjar activity}

Freckled Nightjar activity was quantified as the total number of birds heard or seen along a 14.6-km route. The route was the same as that used for aerial insect sampling, but with an additional $4.5-\mathrm{km}$ section. We did not attempt to distinguish between foraging and breeding activity. Laying dates for C. t. granosus are August-December (Spottiswoode and Jackson 2005). However, since most of the transect was $>300 \mathrm{~m}$ away from rocky outcrops where Freckled Nightjars roosted and nested, we are confident that most birds we observed were foraging. Two transects to assess nightjar activity were driven each night, commencing ca. 10 min after the end of each aerial insect transect. During each transect, the vehicle was driven at the same speed as during the aerial insect transect. In addition, the observer(s) spent $12 \mathrm{~min}$ at each of five observation points selected at the start of the study, during which time the vehicle's engine and lights were switched off and the sky was scanned using a night vision monocular (Yukon model NV MT 24027). Nightjars that were observed flying and/or sitting on the road were identified using a 
handheld spotlight, binoculars, and/or the night vision monocular. Freckled Nightjars are easily distinguishable from other caprimulgid species that occur at KMR in summer on the basis of their larger size and more uniform plumage (Spottiswoode and Jackson 2005).

\section{Data analysis}

We examined the effects of $T_{\mathrm{a}}$ and light levels on aerial insect density and nightjar activity using general linear models (GLM), with aerial insect density or nightjar activity as the response variable, and $T_{\mathrm{a}}$ (continuous), light level (categorical, score $0-5$ ), time from sunset (continuous) and relative humidity (continuous) as predictor variables. Where necessary, variables were transformed to meet assumptions of normality. Although it can be argued that factors such as season and moon phase should be included, the strong collinearity with $T_{\mathrm{a}}$ and light levels respectively prompted us to opt for a simplified analysis. All analyses were conducted using Statistica. Unless otherwise stated, values are presented as means $\pm \mathrm{SD}$.

\section{Results}

\section{Aerial insect density and community composition}

A total of 7,378 insects $>3 \mathrm{~mm}$ in length were caught during 77 transect samples. The density of aerial insects varied among nights by over three orders of magnitude, from $<1.0$ insects $1,000 \mathrm{~m}^{-3}$ on several winter nights to 117.1 insects $1,000 \mathrm{~m}^{-3}$ on a transect begun 30 min after sunset on a warm, humid summer night (Fig. 1). Aerial insect density decreased significantly with $T_{\text {a }}$ (GLM: $F_{1,76}=13.67, P<0.001$ ). Six orders made up $99.9 \%$ of all insects caught, namely Diptera (47.8\%), Coleoptera (20.6\%), Hemiptera (13.6\%), Lepidoptera (12.1\%), Hymenoptera (3.2\%) and Neuroptera (2.5\%).

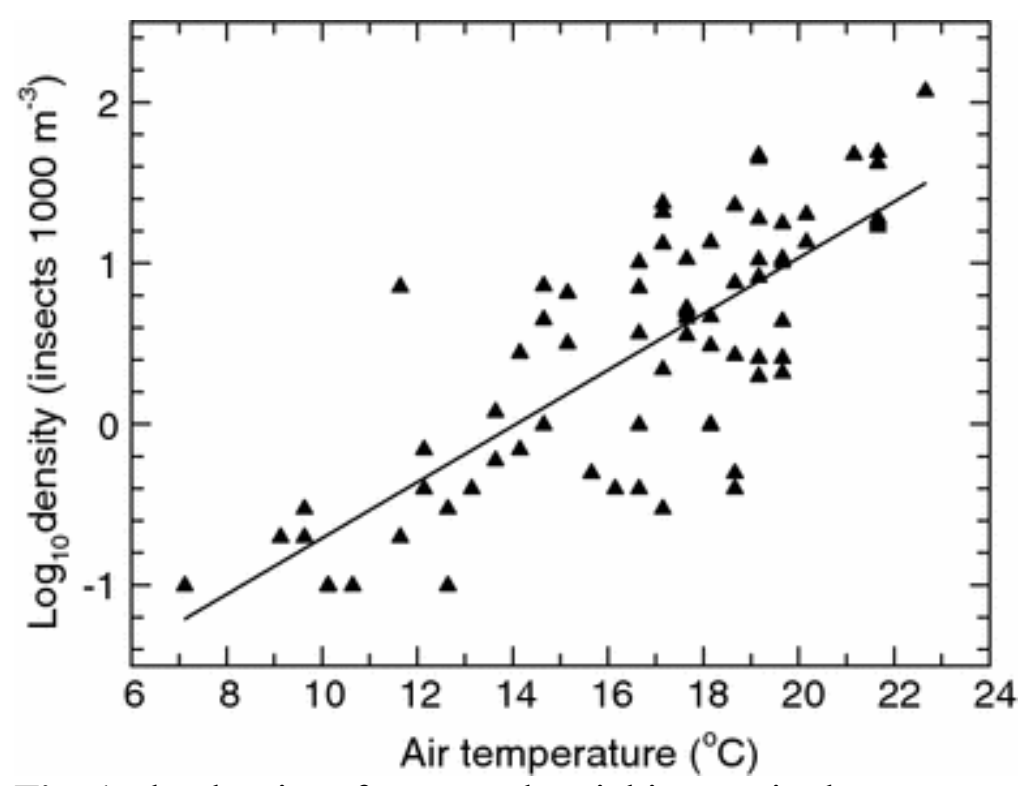

Fig. 1 The density of nocturnal aerial insects in the Kgaswane Mountain Reserve was strongly dependent on air temperature. The solid line represents a least-squares linear 
regression model fitted to the data: $\log _{10}$ density $=0.174 T_{\mathrm{a}}-2.450 ; r^{2}=0.601$, where $T_{\mathrm{a}}$ is air temperature

\section{Nightjar activity}

Freckled Nightjar activity was significantly related to $T_{\mathrm{a}}\left(\mathrm{GLM}: F_{1,76}=8.572\right.$, $P=0.005$ ), with a complete cessation of activity at $T_{\mathrm{a}}<12^{\circ} \mathrm{C}$ (Fig. 2). Nightjar activity was also significantly affected by ambient light levels (GLM: $F$ 5,76 $=7.104, P<0.001$ ), with the number of nightjars recorded markedly reduced on dark nights (Fig. 3). Activity levels observed on nights near full moon averaged $1.95 \pm 2.44$ nightjars transect ${ }^{-1}$, whereas the corresponding value around new moon was only $0.17 \pm 0.61$ nightjars transect $^{-1}$.

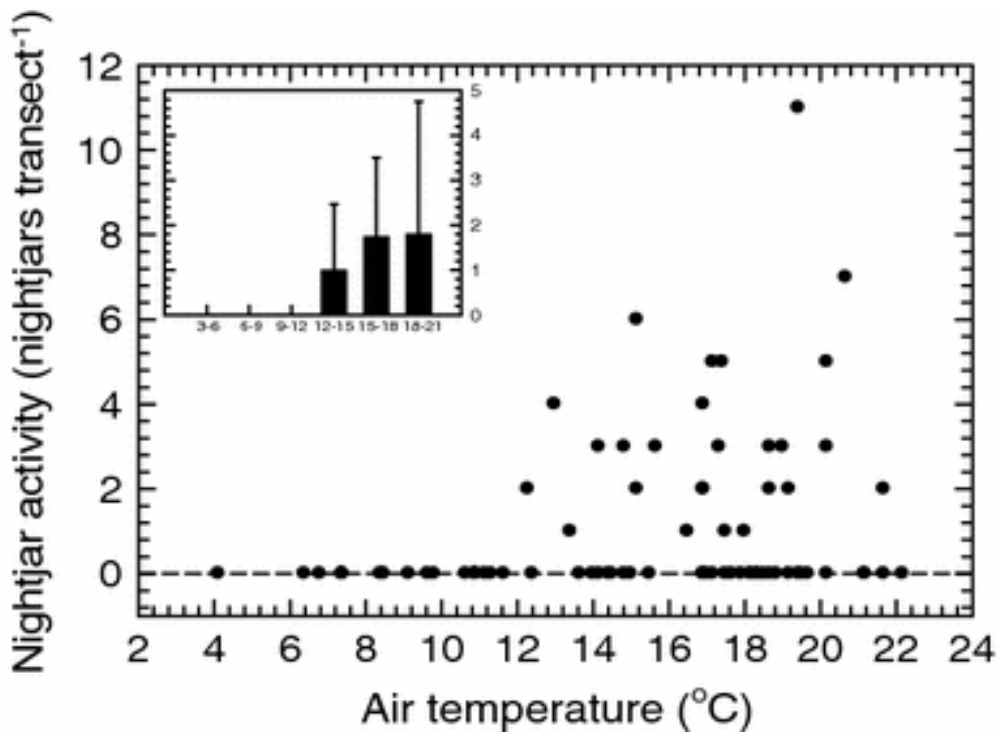

Fig. 2 Freckled Nightjar (Caprimulgus tristigma) activity in the Kgaswane Mountain Reserve increased at higher air temperatures $\left(T_{\mathrm{a}}\right)$, and ceased at $T_{\mathrm{a}}<12^{\circ} \mathrm{C}$. The inset graph shows mean $\pm \mathrm{SD}$ activity classified by $3{ }^{\circ} \mathrm{C}$ intervals in $T_{\mathrm{a}}$

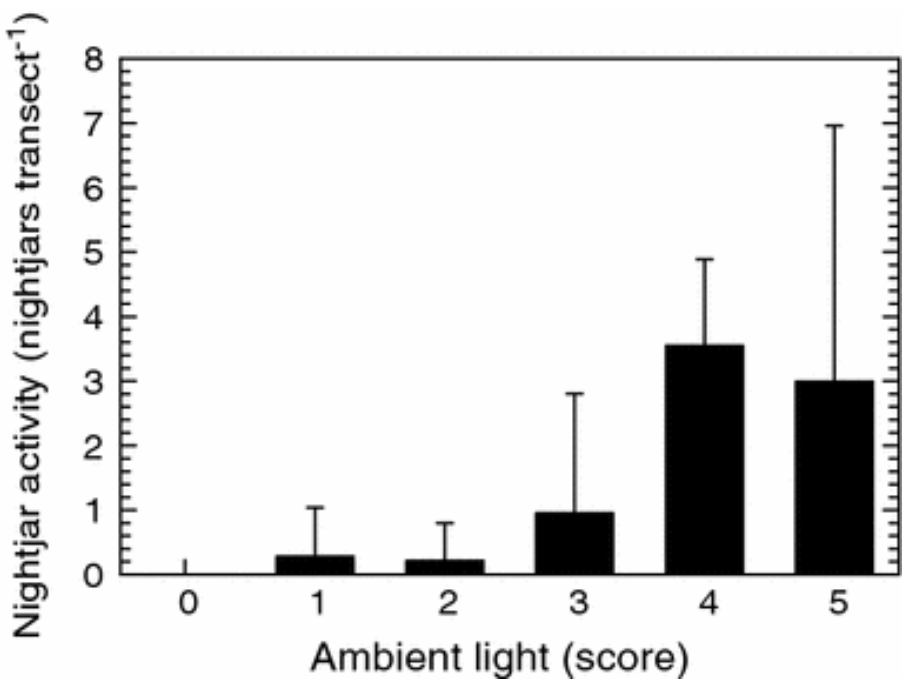


Fig. 3 Freckled Nightjars (Caprimulgus tristigma) in Kgaswane Mountain Reserve were considerably more active when light levels were higher. We scored light levels on a scale of $0-5$, where $0=$ complete darkness with $100 \%$ cloud cover and/or mist, and $5=\mathrm{a}$ completely clear night at full moon

\section{Discussion}

The marked reduction in Freckled Nightjar activity levels at low $T_{\text {a }}$ supports the prediction that temperature is a major determinant of foraging activity in this species in seasonal, subtropical environments. The cessation of activity at $T_{\mathrm{a}}<\mathrm{ca} .12^{\circ} \mathrm{C}$ likely reflects reduced aerial insect densities at low $T_{\mathrm{a}}$. The strong temperature-dependence of C. tristigma activity in our study contrasts with the patterns observed in C. climacurus and $M$. longipennis by Jetz et al. (2003). Although the latter authors found that $T_{\mathrm{a}}$ was a significant predictor variable in the best-fit model for twilight foraging activity in each species, the respective partial coefficients for the effect of $T_{\text {a }}$ were opposite in direction. The overall stronger influence of $T_{\mathrm{a}}$ on activity in C. tristigma likely reflects the larger seasonal variation in monthly minimum $T_{\mathrm{a}}$ at $\mathrm{KMR}\left(2.9-17.3^{\circ} \mathrm{C}\right)$ compared to the study site of Jetz et al. (2003) in Côte d' Ivoire (ca. $16-24^{\circ} \mathrm{C}$ ).

Activity patterns in C. tristigma were also strongly light-dependent, with a marked decrease on dark nights. Similar patterns have been observed in other caprimulgids (Jackson 2003; Jetz et al. 2003; Mills 1986), although the relationship between activity and light is modified by factors such as foraging mode and predation risk (Brigham and Barclay 1992; Brigham et al. 1999; Woods and Brigham 2008). Since the major source of nocturnal light is moonlight, foraging activity in caprimulgids is usually closely linked to moon phase (Brigham and Barclay 1992; Brigham et al. 1999; Jackson 1973; Jetz et al. 2003; Mills 1986). In our study, light levels were influenced by light pollution from the nearby town of Rustenburg, but we nevertheless recorded much higher activity levels around full moon.

Freckled Nightjars at KMR use a food resource that is highly variable through time. The densities of aerial insects we encountered at KMR are lower than those reported by Jetz et al. (2003). In the latter study, 82,663 insects (including a few arachnids) were caught in 127 transects, each $5 \mathrm{~km}$ long, equivalent to an approximate average density of 144 insects $1,000 \mathrm{~m}^{-3}$. Pipistrelle bats (Pipistrellus pipistrellus) in Scotland, in contrast, foraged in areas where aerial insect density ranged from 300 to $>3,000$ insects $1,000 \mathrm{~m}^{-3}$ (Racey and Swift 1985).

On account of their nocturnal habits and diet of aerial insects, energy intake in caprimulgids is limited by temporal variability in prey abundance and physiological/anatomical constraints related to vision (Jetz et al. 2003). This avian taxon exhibits several physiological traits that promote energy conservation, including low basal metabolic rates (Lane et al. 2004b) and a pronounced capacity for torpor (Bartholomew et al. 1957; Brigham 1992; Brigham et al. 2000; Dawson and Fisher 1969; Fletcher et al. 2004; Körtner et al. 2000; Lane et al. 2004a). During winter, Freckled 
Nightjars at KMR enter torpor, down-regulating body temperature $\left(T_{\mathrm{b}}\right)$ by up to ca. $25^{\circ} \mathrm{C}$ below normothermic levels (McKechnie et al. 2007). These physiological traits have clear adaptive value in caprimulgids because they reduce the severity of mismatches between energy supply and demand.

In summary, our study reveals a strong effect of $T_{\mathrm{a}}$ on activity in a nocturnal aerial insectivore that inhabits a seasonal, subtropical environment, and reiterates the constraints on matching energy supply and demand that small endotherms can face at low environmental temperatures. Our data for C. tristigma, although confined to one study site during one year, also raise the possibility that the environmental determinants of activity in caprimulgids vary among habitats. The available evidence suggests that, in warm, tropical environments, caprimulgid foraging activity is determined primarily by light levels (Jetz et al. 2003). Our study reveals that in cooler, more seasonal, environments temperature as well as light levels can strongly affect activity patterns, although further studies from a wider range of subtropical and temperate species are required to verify the generality of this observation.

\section{Zusammenfassung}

\section{Beziehungen zwischen Umweltparametern und Aktivitätsmustern der Fleckennachtschwalbe (Caprimulgus tristigma) in einem subtropisch saisonalen Lebensraum}

Untersucht wurden die Einflüsse von Umweltparametern auf die Aktivität der Fleckennachtschwalbe (Caprimulgus tristigma), einem nachtaktiven, im Flug Insekten erbeutenden Standvogel der kühleren und trockeneren Bereiche Südafrikas. Wir haben speziell die Hypothese getestet, dass die Lufttemperatur (Tl) in Verbindung mit der Lichtverfügbarkeit signifikant mit der Aktivität der Fleckennachtschwalbe korreliert. Es zeigte sich, dass die Dichte an Fluginsekten im Laufe der Untersuchung über einen Bereich von 3 Größenordnungen schwankte (von $<1,0$ bis zu 117,1 Insekten je $1000 \mathrm{~m}^{3}$ Luft) und stark positiv mit Tl zusammenhing. Die Nachtschwalbenaktivität war ebenfalls deutlich temperaturabhängig, wobei $\mathrm{ab} \mathrm{Tl}<12^{\circ} \mathrm{C}$ die Aktivität vollständig zum Erliegen kam. Im Einklang mit vorangegangenen Untersuchungen fanden wir heraus, dass die Aktivitätsniveaus stark vom Umgebungslicht abhingen, mit einer in dunklen Nächten merklich verringerten Aktivität. Die durchschnittliche Anzahl an Fleckennachtschwalben pro 14,6 km Transektstrecke betrug 1,95 $\pm 2,44$ Vögel in Nächten um Vollmond, aber nur $0,17 \pm 0,61$ Nachtschwalben um Neumond herum. Unsere Untersuchung macht deutlich, dass die Aktivität von Nachtschwalben signifikant von Temperatur und Umgebungslicht beeinflusst sein kann.

\section{References}

Bartholomew GA, Howell TR, Cade TJ (1957) Torpidity in the white-throated swift, anna hummingbird, and poor-will. Condor 59:145-155 
Brigham RM (1992) Daily torpor in a free-ranging goatsucker, the common poorwill (Phalaenoptilus nuttallii). Physiol Zool 65:457-472

Brigham RM, Barclay RMR (1992) Lunar influence on foraging and nesting activity of Common Poorwills (Phalaenoptilus nuttallii). Auk 109:315-320

Brigham RM, Gutsell RCA, Wiacek RS, Geiser F (1999) Foraging behavior in relation to the lunar cycle by Australian Owlet-nightjars (Aegotheles cristatus). Emu 99:253-261

Brigham RM, Körtner G, Maddocks TA, Geiser F (2000) Seasonal use of torpor by freeranging Australian owlet-nightjars (Aegotheles cristatus). Physiol Biochem Zool 73:613620

Brigham RM, Woods CP, Lane JE, Fletcher QE, Geiser F (2006) Ecological correlates of torpor use among five caprimulgiform birds. Acta Zool Sinica 52(suppl):401-404

Cleere N (1999) Family Caprimulgidae (nightjars). In: del Hoyo J, Elliot A, Sargatal J (eds) Handbook of the birds of the world, vol 5. Lynx, Barcelona, pp 302-386

Dawson WR, Fisher CD (1969) Responses to temperature by the spotted nightjar (Eurostopodus guttatus). Condor 71:49-53

Fletcher QE, Fisher RJ, Willis CKR, Brigham RM (2004) Free-ranging common nighthawks use torpor. J Therm Biol 29:9-14

Holyoak DT (2001) Nightjars and their allies: the Caprimulgiformes. Oxford University Press, Oxford

Jackson HD (1973) Records of some birds and mammals in the central Chimanimani Mountains of Moçambique and Rhodesia. Durban Mus Novit 9:23-42

Jackson HD (2000) Prey size in relation to mouth size of nightjars in Zimbabwe. Ostrich $71: 436-437$

Jackson HD (2003) A review of foraging and feeding behaviour, and associated anatomical adaptations, in Afrotropical nightjars. Ostrich 41:187-204

Jetz W, Steffen J, Linsenmair KE (2003) Effects of light and prey availability on nocturnal, lunar and seasonal activity of tropical nightjars. Oikos 103:627-639 
Körtner G, Brigham RM, Geiser F (2000) Winter torpor in a large bird. Nature 407:318

Lane JE, Brigham RM, Swanson DL (2004a) Daily torpor in free-ranging whip-poorwills (Caprimulgus vociferus). Physiol Biochem Zool 77:297-304

Lane JE, Swanson DL, Brigham RM, McKechnie AE (2004b) Physiological responses to temperature by Whip-poor-wills: more evidence for the evolution of low metabolic rates in caprimulgiformes. Condor 106:921-925

McKechnie AE, Ashdown RAM, Christian MB, Brigham RM (2007) Torpor in an Afrotropical caprimulgid, the Freckled Nightjar (Caprimulgus tristigma). J Avian Biol 38:261-266

Mills AM (1986) The influence of moonlight on the behavior of goatsuckers (Caprimulgidae). Auk 103:370-378

Racey PA, Swift SM (1985) Feeding ecology of Pipistrellus pipistrellus (Chiroptera, Vespertilionidae) during pregnancy and lactation. I. Foraging behavior. J Anim Ecol $54: 205-215$

Rydell J, Entwistle A, Racey PA (1996) Timing of foraging flights of three species of bats in relation to insect activity and predation risk. Oikos 76:243-252

Sibley CG, Ahlquist JE (1990) Phylogeny and classification of birds. Yale University Press, New Haven

Speakman JR Rydell J, Webb PI, Hayes JP, Hays GC, Hulbert IAR, McDevitt RM (2000) Activity patterns of insectivorous bats and birds in northern Scandinavia $\left(69^{\circ} \mathrm{N}\right)$, during continuous midsummer daylight. Oikos 88:75-86

Spottiswoode CN, Jackson HD (2005) Freckled nightjar. In: Hockey PAR, Dean WRJ, Ryan PG (eds) Roberts birds of southern Africa. The Trustees of the John Voelcker Bird Book Fund, Cape Town

Woods CP, Brigham RM (2008) Common poorwill activity and calling behavior in relation to moonlight and predation. Wilson J Ornithol (in press) 